\title{
ANALISIS FAKTOR PERSEDIAAN BARANG DAN PERMINTAAN PASAR TERHADAP PROFITABILITAS PT. EKO AGRO MANDIRI LAMONGAN
}

\author{
*( Haris Bashory Ismail \\ Prodi Manajemen, Fakultas Ekonomi, Universitas Islam Lamongan \\ Jl. Veteran No.53A Lamongan \\ Telp. ( 0322 ) 324706, Faks. ( 0322 ) 324706 \\ Email :jpim.unisla@gmail.com
}

\begin{abstract}
ABSTRAK
Penelitian ini bertujuan untuk melakukan analisis pengaruh faktor persediaan barang dan permintaan pasar terhadap profitabilitas pada PT. Eko Agro Mandiri Lamongan. Data yang diamati adalah data perediaan, permintaan pasar dan NPM dari produk pupuk organik untuk periode 2009-2013. Teknik analisis yang digunakan menggunakan pendekatan statistik parametrik regresi linier berganda, uji t dan uji F. Temuan penelitian menyimpulkan bahwa faktor persediaan barang dan permintaan pasar secara parsial terbukti berpengaruh signifikan terhadap profitabilitas. Pada uji simultan, di dapatkan simpulan bahwa model menunjukkan prediktor yang tepat pada profitabilitas perusahaan. Sementara analisis pengaruh dominan menunjukkan bahwa permintaan pasar menunjukkan pengaruh dominan atas profitabilitas perusahaan atas penjualan produk pupuk organik.
\end{abstract}

Kata kunci: Persediaan barang, Permintaan pasar, Profitabilitas

\section{PENDAHULUAN}

Barang dan jasa diproduksi atas dua motivasi utama, yaitu untuk memenuhi kebutuhan (needs) dan keinginan (wants) konsumen. Kebutuhan dan keinginan tersebut adalah pemicu utama dari permintaan pasar (market demands) atas suatu produk. Pasar tercipta karena ada permintaan dan penawaran, Umar 2010. Perubahan permintaan akan suatu barang atau jasa tersebut akan dapat dilihat dari perubahan pada kurva permintaan. Maka analisis permintaan akan suatu barang atau jasa erat kaitanya dengan perilaku konsumen. Konsumen adalah mereka yang memiliki pendapatan (uang) dan menjadi pembeli barang dan jasa di pasar ( Adiningsih dan Kadarusman, 2013 ).. Permintaan meruakan jumlah dari suatu barang atau jasa yang mau dan mampu dibeli pada pelbagai kemungkinan harga selama jangka waktu tertentu dengan anggapan halhal lain tetap sama (ceteris paribus) Gilarso, 2012

Pada produk-produk yang terkait dengan pertanian (agrobisnis), supplai atas barang tersebut timbul karena adanya permintaan pasar yang besar. Indonesia yang secara geografis terletak di belahan khatulistiwa memunkinkan adanya sistem cocok tanam (agro) karena beriklim tropis dan kondisi tanah yang subur. Hal inilah yang menyebabkan selain 
Indonesia dikenal sebagai negara maritim (negara dengan wilayah laut yang besar) juga dikenal dengan keunggulan sektor pertaniannya. Mayoritas penduduk di Jawa dan Luar Jawa bekerja menggantungkan hidupkan di sektor pertanian, hal ini telah berlangsung secara turun temurun selama ratusan tahun.

Besarnya potensi pasar pertanian ini memberikan peluang-peluang bagi penyediaan produk pertanian, terutama kebutuhan akan pupuk. Walaupun di Indonesia pasar pupuk di kuasai oleh pupuk kimiawi (non organik), namun dengan meningkatkan kesadaran akan pentingnya produk ramah lingkungan akan menjadi pendorong bagi kemajuan produk pupuk organik. Gejala ini dapat dilihat dengan animo masyarakat untuk membeli produkproduk pertanian organik, dan komoditas organik umumnya lebih mahal daripada komoditas dengan pemupukan non organik.

Kabupaten Lamongan merupakan salah satu daerah di Indonesia dengan potensi pertanian yang sangat besar. Struktur ekonomi di Lamongan, pertanian masih merupakan sektor andalan dan utama. Berdasarkan angka hasil pencacahan Sensus Pertanian 2013, jumlah rumah tangga usaha pertanian di Lamongan masih mencapai 189.223 walaupun angka ini mengalami penurunan dibandingkan data tahun 2003 ( BPS 2014 ), namun dengan jumlah tersebut menunjukkan bahwa masih potensi pasar terhadap produk-produk agro bisnis khususnya pupuk pertanian masih menjanjikan.
PT. Agro Mandiri adalah perusahaan yang bergerak dalam supplai pupuk organik pertanian yang berlokasi di Pangean Kecamatan Sekaran Kabupaten Lamongan. Dengan potensi pasar yang besar yang dimiliki Kabupaten Lamongan, perusahaan yang berdiri di 2002 ini telah tumbuh cukup pesat. Perusahaan saat ini telah memproduksi tiga kategori produk organik, antara lain pupuk kompos dengan berbagai kemasan, pupuk organik cair seperti MOL (mikro organisme lokal) dengan berbagai ukuran, maupun petsida organik.

Walaupun dengan potensi pasar yang besar di Lamongan, namun pesaing utama produk organik adalah produk pupun non organik yang dikuasai perusahaan besar, dan menjadi leader market. Bila diamati dari pola pertumbuhan penjualan perusahaan nampak bahwa pada era dimana pupuk non organik langka dan dibatasi subsidinya pemasaran produk organik menpatkan momennya untuk tumbuh dan berkembang. Antara tahun 2005-hingga 2009 penjualan untuk tiga kelompok produk yang dijual oleh PT. Eko Agro Mandiri yaitu pupuk organik cair, pupuk organik kompos, dan petsida organik, mampu tumbuh sekitar $36 \%$ per tahunnya. Namun pada akhir tahun 2013 penjualan perusahaan mengalami stagnasi dengan tingkat pertumbuhan hanya $1 \%$ rata-rata per tahun untuk tiga tahunnya. Ini artinya penjualan produk organik sangat dipengaruhi oleh tingkat permintaan pasar. 
Pupuk organik sendiri merupakan substitusi dari produk an organik yang masih digunakan oleh banyak petani di Lamongan, oleh sebab itu pertumbuhan permintaan dipengaruhi oleh harga-harga pupuk non organik sendiri. Tahun 2013 menunjukkan adanya trend penurunan penggunaan pupuk organik khususnya pupuk kompos dan petsida organik. Hal ini seiring dengan peningkatan perhatian pemerintah untuk meningkatkan subsidi pertanian.

Selain masalah permintaan pasar, faktor lain yang mempunyai peran penting adalah tingkat ketersediaan pupuk organik. Besar kecilnya persediaan volume yang dibutuhkan untuk melindungi jalannya perusahaan, volume produksi yang direncanakan, besar pembeliaan bahan mentah setiap kali pembelian untuk mendapatkan biaya pembelian yang minimal, estimasi tentang fluktuasi harga bahan mentah, peraturanperaturan pemerintah yang menyangkut persediaan material, harga pembelian bahan mentah dan biaya penyimpanan dan resiko penyimpanan di gudang maupun tingkat kecepatan material menjadi rusak atau turun kualitasnya (Riyanto, 2010)

Assauri menjelaskan (2010, p. 152) persediaan barang jadi (Finished goods stock) sebagai barang yang telah selesai diproses dan siap untuk dijual kepada pelanggan atau perusahaan lain. Sebagai barang jadi artinya persediaan (inventory) akan berperan penting dalam menjaga supply untuk memenuhi permintaan pasar. Ketika seluruh kebutuhan yang ada dapat dipenuhi dengan baik oleh perusahaan maka pendapatan perusahaan akan meningkat. Pada akhirnya return usaha perusahaan juga akan mengalami peningkatan.

Berbeda dengan pupuk kimiawi yang diproduksi masal dengan teknologi yang sangat baik, produsen pupuk organik umumnya dikerjakan secara tradisional dengan peralatan semi manual. Hal ini menjadikan ketersediaan produk juga sangat terbatas dibandingkan pupuk kimiawi. Keterbatasan bahan baku juga akan menentukan tingkat supplai perusahaan, karena akan mempengaruhi kapasitas produk yang dihasilkan oleh perusahaan. Ketika ketersediaan produk organik rendah, maka konsumen akan kembali mengandalkan produk pupuk an organik.

Temuan penelitian terdahulu juga menujukkan adanya hubungan yang kuat antara persediaan dan persediaan dengan tingkat profitabilitas usaha. Puspitasari (Analisis Faktor Persediaan Barang dan Permintaan Pasar Terhadap Profitabilitas Industri Kerajinan Tenun Tikar "Nisaz" Lamongan, 2013) menemukan bahwa faktor persediaan maupun permintaan pasar mempunyai dampak yang sangat penting terhadap keuntungan perusahaan. Begitu juga pada penelitian Jannah (Hubungan Kenaikan Harga Bahan Bakar Minyak (BBM) \& Permintaan Pasar terhadap Profitabilitas Industri Kayu di Blitar, 2010) memberikan indikasi yang kuat hubungan antara permintaan pasar 
dengan tingkat keuntungan perusahaan.

\section{LANDASAN TEORI}

Menurut Baridwan persediaan digunakan untuk menunjukkan barang-barang yang dimiliki untuk dijual kembali atau digunakan untuk memproduksi barang-barang yang dijual. Persediaan menurut Harnanto adalah meliputi semua barang yang dimiliki dengan tujuan untuk dijual kembali dan atau dikonsumsi dalam operasi normal perusahaan. Menurut Kieso, dkk persediaan adalah pos-pos aktiva yang dimiliki untuk dijual dalam operasi bisnis normal atau barang yang akan digunakan atau dikonsumsi dalam memproduksi barang yang akan dijual.

Fungsi permintaan ( demand function) adalah persamaan yang menunjukkan hubungan antara jumlah permintaan suatu barang dan semua faktor-faktor yang mempengaruhinya.

Pengertian Rasio Profitabilitas adalah merupakan rasio utama dalam seluruh laporan keuangan, karena tujuan utama perusahaan adalah hasil operasi/ keuntungan. Keuntungan adalah hasil akhir dari kebijakan dan keputusan yang diambil manajemen. Rasio keuntungan akan digunakan untuk mengukur keefektifan operasi perusahaan sehingga menghasilkan keuntungan pada perusahaan. Rasio profitabilitas sangat penting bagi semua pengguna laporan tahunan, khususnya investor ekuitas dan kreditor. Bagi investor ekuitas, laba merupakan satu-satunya faktor penentu perubahan nilai efek / sekuritas. Pengukuran dan peramalan laba merupakan pekerjaan paling penting bagi investor ekuitas. Bagi kreditor, laba dan arus kas operasi umumnya merupakan sumber pembayaran bunga dan pokok.

\section{METODE PENELITIAN}

Umar (Riset Pemasaran dan Perilaku Konsumen, 2010) menjelaskan umumnya desain penelitian dapat dikelompokkan menjadi tiga: desain penjajakan, desain deskriptif, desain kausal dan desain acak sempurna. Penelitian ini dapat dikategorikan kedalam desain kausal, karena dalam desain kausal menganalisis hubungan-hubungan antara satu varaibel dengan variabel lainnya, atau bagaimana variabel mempengaruhi variabel lainnya. Sifat hubungan yang mungkin terjadi dapat berupa hubungan simetris, asimetris dan timbal balik.

Populasi penelitian ini adalah data runtut waktu (timeseries) untuk variabel volume persediaan, permintaan dan profitabiltias pada operasi PT. Eko Agro Mandiri. Sementara itu Dalam penelitian ini tidak menggunakan subyek penelitian namun menggunakan data pengamatan waktu. Sampel yang diambil adalah data 5 tahun terakhir dari operasional PT. Eko Agro Mandiri, yaitu data tahun 2009-2013 yang terdiri data rutunt waktu untuk volume permintaan, volume persediaan, dan rasio profitabilitas perusahaan pada periode 2009-2013. Teknik pengambilan sampel dalam penelitian ini menggunakan metode 
non probability sampling atau pengambilan sampel non acak dengan metode purposive sampling. Pengambilan data secara purposive adalah metode pemilihan sampel dengan memberikan batasan kriteria tentang sampel yang diambil. Kriteria yang digunakan dalam penelitian ini adalah sampel yang mewakili kondisi aktual saat ini, oleh sebab itu sampel terpilih adalah sampel data 6 tahun terakhir. Data 6 tahun terakhir dianggap lebih tepat mewakili fenomea saat ini, sehingga relevan dikaji dan dianalisis.

Adapun variabel bebas dalam penelitian ini antara lain: Persediaan dan Permintaan pasar. Persediaan (X1) merupakan aktiva jangka pendek yang meliputi barang-barang hasil proses produksi baik barang dalam proses proses maupun barang jadi dengan tujuan untuk dijual kepada konsumen. Data persediaan dinyatakan dalam unit, dan data pengamatan dilakukan mulai 20092013. Sementara itu permintaan (X2) adalah jumlah produk yang dibutuhkan oleh konsumen untuk memenuhi kebutuhannya pada berbagai tingkatan harga dalam periode tertentu. Data permintaan dinyatakan dalam unit, dengan waktu pengamatan mulai 2009-2013. Sebagai variabel terikat, Profitabilitas (Y). Profitabilitas di definisikan sebagai tingkat keuntungan perusahaan atas produk-produk yang dijual setelah dikurangi dengan bebanbeban baik beban langsung maupun tidak langsung. Pengukuran profitabilitas menggunakan rasio
NPM yaitu perbandingan antara penjualan dan laba bersih.

\section{HASIL PENELITIAN DAN PEMBAHASAN \\ Hasil Penelitian}

Uji prasyarat yang dilakukan dengan menggunakan uji asumsi klasik menunjukkan bahwa model penelitian telah menunjukkan model yang memenuhi syarat untuk dianalisis. Uji normalitas dengan Kolmogorov Smirnov pada data multivariate absolute unstandardized residual di dapatkan nilai distribusi $\mathrm{Z}$ Kolmogorov-Smirnov sebesar 0.666 dengan Asymptotic Significance sebesar 0,767. Uji multikolinieritas menggunakan Colonierity Statistic pada Output regresi, dapatkan bahwa nilai VIF Persediaan (X1) sebesar 2,920, dan Variabel Permintaan (X2) dengan nilai VIF 2,920 yang menunjukkan model terbebas dari gejala kolinieritas ganda. Uji heterokedastisitas dengan Glejser test, didapatkan nilai korelasi bivariate antara variabel persediaan (X1) dengan error mempunyai korelasi yang rendah yaitu 0,239 dengan Signifikansi 0,649 yang berarti tidak terbukti signifikan. Begitu juga pada variabel permintaan (X2) di dapatkan korelasi yang sangat rendah yaitu 0,001 dengan signifikansi 0,998. Sementara uji autokorelasi didapatkan DW Tabel dengan derajat kebebasan 3 dan $\mathrm{k}=2$ pada alpha $5 \%$ di dapatkan DL sebesar 0,629 dab DU sebesar 1,6693 dengan demikin 4-DL sebesar 3,371 dan 4-DU sebesar 1,949. 
Tabel 1.

Analisis Regresi Linier Berganda

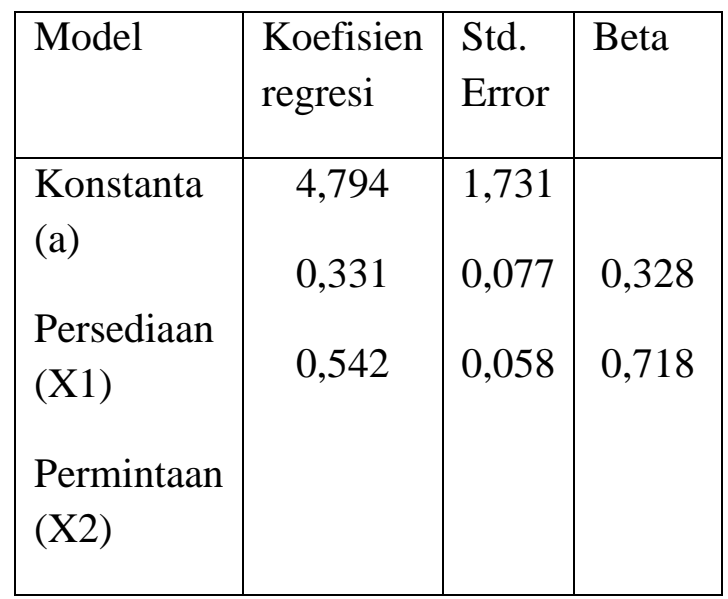

Sumber: Lampiran 1

Hasil analisis data terhadap datadata pada variabel yang diteliti dapatkan model persamaan regresi untuk menjelaskan pengaruh antara persediaan barang dan permintaan pasar terhadap profitabilitas dalam persamaan matematis regresi $\mathrm{Y}=$ $4,794+0,331(\mathrm{X} 1)+0,542(\mathrm{X} 2)+\mathrm{e}$

Model persamaan diatas menjelaskan bahwa besarnya nilai konstanta adalah sebesar 4,794. Konstanta merupakan besaran nilai tetap ketika nilai dari keseluruhan variabel bebas diasumsikan nol atau cateris paribus. Konstanta menunjukkan angka konstan dalam persamaan. Nilai konstanta yang ditunjukkan oleh persamaan diatas adalah 4,794 yang berarti jika di asumsikan variabel lain nol atau cateris paribus maka nilai profitabilitas adalah 4,794.

Sementara pengaruh dari varaibel permintaan terhadap profitabilitas ditunjukkan dengan nilai koefisien 0,331. Koefisien tersebut mencerminkan dampak (effect) perubahan yang disebabkan oleh terjadinya perubahan pada variabel Persediaan perusahaan. Nilai koefisien 0,331 mencerminkan bahwa setiap kenaiakan pada nilai Persediaan tiap ribuan unitnya akan dapat mendorong terjadinya kenaikan profitabilitas pada PT. Eco Agro Mandiri Pangean Maduran Lamongan dengan besaran kenaikan 0,331 dan asumsi variabel lain konstan. Sebaliknya terjadinya penuruan jumlah Persediaan tiap ribuan unitnya dapat juga berdampak pada penurunan tingkat Profitabilitas sebesar 0,331 persen.

Pengaruh variabel permintaan terhadap Profitabilitas PT. Eco Agro Mandiri Pangean Maduran Lamongan dalam persamaan tersebut ditunjukkan nilai koefisin 0,542 dengan arah pengaruh variabel tersebut bersifat positif atau searah. Ini berarti bahwa setiap kenaikan dari jumlah Permintaan oleh pasar tiap ribuan unitnya akan direspons kenaikan profitabilitas perusahaan sekitar 0,542 persen, dengan asumsi variabel lain konstan atau cateris paribus. Sebaliknya terjadinya penuruan nilai atas variabel tersebut dapat menekan Profitabilitas PT. Eco Agro Mandiri hingga sebesar 0,542 untuk tiap unitnya.

Hasil analisis koefisien determinasi pada model penelitian di dapatkan nilai $\mathrm{R}$ sebesar 0,997 dan $\mathrm{R}$ Square sebesar 0,994. Nilai tersebut menjelaskan bahwa variabel prediktor dalam persamaan penelitian ini yaitu Persediaan, dan permintaan Konsumen dapat menentukan tingkat perubahan varian dari variabel 
Profitabilitas pada PT. Eco Agro Mandiri Pangean Maduran Lamongan sebesar 0,994 atau 99,4\%. Sisanya $0,6 \%$ merupakan variabel-variabel diluar variabel prediktor tersebut.

Pengujian hipotesis pertama dengan menggunakan uji $\mathrm{F}$ hitung di dapatkan model yang fit sebagai prediktor terhadap profitabilitas perusahaan. Hasil $\mathrm{F}$ hitung adalah sebesar 250,403 dengan signifikansi 0,000. Pada tingkat derajat kepercayaan $95 \%$ maka dapat disimpulkan H0 ditolak. Hasil ini memberikan simpulan bahwa model prediktor yang terdiri diri dari dua variabel yaitu Persediaan dan permintaan pasr secara bersama merupakan prediktor yang tepat terhadap Profitabilitas pada PT. Eco Agro Mandiri Pangean Maduran Lamongan. Persediaan, Permintaan dan Loyalitas Konsumen secara bersama-sama terbukti mempunyai pengaruh signifikan terhadap Profitabilitas pada PT. Eco Agro Mandiri Pangean Maduran Lamongan.

Tabel 2.

Uji Signifikansi Model Parsial

\begin{tabular}{|c|r|c|l|}
\hline Variabel & $\begin{array}{c}\mathrm{t} \\
\text { hitung }\end{array}$ & Sig & Keputusan \\
\hline Persediaan & 4,307 & 0.023 & Ho ditolak \\
\hline Permintaan & 9,350 & 0.003 & Ho ditolak \\
\hline \multicolumn{4}{|l}{ Sumber : Lampiran 2 }
\end{tabular}

Signifikansi pengaruh Persediaan terhadap Profitabilitas.

Hasil uji $t$ hitung pengaruh variabel Persediaan terhadap
Profitabilitas PT. Eco Agro Mandiri Pangean Maduran Lamongan di dapatkan nilai t hitung 4,307 dengan signifikansi 0,032. Hasil diatas menjelaskan bahwa variabel Persediaan terbukti mempunyai pengaruh yang bermakna terhadap Profitabilitas pada PT. Eco Agro Mandiri Pangean Maduran Lamongan.

Pengujian terhadap signifikansi pengaruh variabel Permintaan terhadap Profitabilitas pada PT. Eco Agro Mandiri Pangean Maduran Lamongan di dapatkan nilai t hitung 2,793 dengan signifikansi 0,038. Temuan tersebut menunjukan bahwa variabel Permintaan terbukti berpengaruh signifikan terhadap Profitabilitas pada PT. Eco Agro Mandiri Pangean Maduran Lamongan.

Analisis pengaruh masing masing variabel dalam model menunjukkan kedua variabel bebas yang diteliti mempunyai pengaruh positif terhadap kemampuan perusahaan mencetak laba atau profit. Pengaruh pada variabel persediaan ditunjukkan besaran koefisien regresi sebesar 0,003 sementara untuk permintaan mencapai 0,542. Nilai koefisien regresi tersebut mendeskripsikan bahwa setiap terjadi kenaikan pada persediaan mampu meningkatkan profitabilitas sebesar 0,331 sementara pada permintaan mampu mendorong profitabilitas sebesar 0,542. Sebaliknya setiap penurunan yang terjadi pada variabel akan berdampak pada tekanan profitabiltias sebesar 0,331 sementara pada permintaan akan menekan sebesar 0,542 pada profitabilitas perusahaan. 
Analisa berdasarkan kekuatan asosiatif pada variabel yang diteliti menunjukkan adanya hubungan yang kuat antara model yang diteliti dengan profitabilitas. Besarnya nilai $\mathrm{R}$ di dapatkan nilai 0,997 sementara $R$ square di dapatkan angka 0,994. Hasil ini menunjukkan besarnya kemapuan variabel yang diteliti mampu menjelaskan profitabilitas, yaitu mencapai $99,4 \%$.

Uji pengaruh secara simultan variabel persediaan dan permintaan terhadap profitabilitas menyimpulkan adanya pengaruh simultan yang signifikan kedua variabel bebas yang diteliti terhadap profitabilitas PT. Eco Agro Mandiri. Hasil Uji F hitung di dapatkan nilai F hitung sebesar 250,04 dengan probabilitas untuk menerima H0 sebesar 0\%, dengan demikian hipotesis yang menyatakan bahwa persediaan dan permintaan secara simultan berpengaruh terhadap profitabilitas diterima, dan hipotesis yang menolak hipotesis tersebut tidak terbukti. Tinjauan atas koefisien korelasi berganda menunjukkan nilai sebesar 0,997 sementara nilai determinasi berganda mencapai 0,994. Ini menunjukkan dari sisi hubungan variabel dalam model secara bersamasama mempunyai hubungan yang sangat kuat, sementara dari aspek determinasi atau kemampuan model menjelaskan variabel terikat mencapai 0,994 atau 99,4\% variabel persediaan dan permintaan mampu menjelaskan setiap perubahan yang terjadi pada profitabilitas PT. Eco Agro Mandiri Pangean Sekaran Lamongan.
Sementara itu uji hiptesis parsial yaitu pengaruh masing-masing variabel bebas yang diteliti terhadap profitabilitas PT. Eco Agro Mandiri juga terbukti signifikan keduanya. Uji parsial yang dilakukan dengan uji $\mathrm{t}$ hitung menunjukkan bahwa dua variabel yang diteliti terbukti secara parsial berpengaruh terhadap profitabiltitas perusahaan. Hasil uji $\mathrm{t}$ hitung pada variabel persediaan di dapatkan nilai 4,307 dengan signifikansi 0,023 sementara untuk variabel permintaan di dapatkan hasil nilai $\mathrm{t}$ hitung sebesar 9,350 dengan signifikansi menerima H0 hanya 0,003, dengan demikian H0 ditolak untuk kedua variabel tersebut. Artinya hipotesis parsial yang diajukan baik untuk variabel persediaan maupun variabel permintaan terbukti mempunyai pengaruh signifikan terhadap profitabilitas perusahaan.

Uji hipotesis terakhir adalah menguji terhadap dominasi pengaruh diantara variabel persediaan dan permintaan terhadap profitabilitas. Uji ini akan memberikan simpulan tentang mana diantara dua tersebut yang penting menentukan dalam mendorong profitabiltias perusahaan. Analisis koefisien beta menunjukkan bahwa permintaan dominan berpengaruh terhadap profitabilitas dibandingkan dengan persediaan. Nilai koefisien beta parsial untuk variabel permintaan mencapai 0,713 sementara untuk variabel persediaan mencapai 0,328 dengan demikian permintaan mampu memberikan determinan lebih besar dibandingkan 
dengan persedian terhadap profitabilitas.

\section{KESIMPULAN DAN SARAN \\ Kesimpulan}

Variabel persediaan barang maupun permintaan pasar merupakan dua faktor yang penting dalam meningkatkan profitabilitas perusahaan. Temuan-temuan menunjukkan adanya pengaruh baik secara parsial, maupun simultan tentang pengaruh dari variabelvariabel tersebut terhadap profitabilitas. Sementara temuan ketiga menunjukkan diantara dua faktor tersebut, permintaan pasar merupakan faktor paling dominan dalam menentukan kenaikan profitabilitas perusahaan.

\section{Saran}

Terkait dengan temuan penelitian ini, maka perusahaan perlu mendorong permintaan dengan melakukan strategi pemasaran dan pengenalan pada target pasar (khususnya daerah lamongan) akan manfaat dari pupuk organik terhadap kepentingan jangka panjang, seperti kelestarian alam, mengurangi kerusakan lingkungan, dan sisi positif hasil produk agro yang menggunakan pupuk organik bagi kesehatan. Dengan strategi pemasaran tersebut diharapkan kesadaran penggunaan pupuk organik meningkat, dan permintaan perusahaan juga dapat lebih ditingkatkan lagi. Perusahaan juga perlu meningkatkan kapasitas persediaan, serta membuka jaringan penyalur yang lebih banyak. Kapasitas persediaan yang mencukupi dan terkelola dengan baik akan dapat menekan biaya operasional, sementara jaringan penyalur akan membuka jangkauan pasar lebih luas, karena konsumen dapat mengakses produk tersebut lebih mudah.

\section{DAFTAR PUSTAKA}

Adiningsih, S., \& Kadarusman.

(2013). Teori Ekonomi Mikro. Yogyakarta: BPFE.

Assauri, S. (2010). Manajemen

Produksi dan Operasi. Jakarta:

Lembaga Penerbit FE UI.

BPS. (2014). Biro Pusat Statistik.

Retrieved 01 01, 2015, from

Pertanian dan pertambangan:

http://bps.go.id/tab_sub/view.p

hp?kat $=3 \&$ tabel $=1 \&$ daftar $=1 \&$

id_subyek $=54 \&$ notab $=1$

Gilarso, T. (2011). Pengantar Ilmu

Ekonom-Bagian Makro.

Yogyakarta: Pustaka Pelajar.

Harinaldi. (2011). Prinsip-Prinsip

Statistik Untuk Teknik dan

Sains. Jakarta: Erlangga.

Jannah, N. S. (2010). Hubungan

Kenaikan Harga Bahan Bakar

Minyak (BBM) \& Permintaan

Pasar terhadap Profitabilitas

Industri Kayu di Blitar.

Malang: Skripsi Universitas

Islam Negeri Malang.

Puspitasari, D. (2013). Analisis Faktor

Persediaan Barang dan

Permintaan Pasar Terhadap

Profitabilitas Industri

Kerajinan Tenun Tikar

"Nisaz" Lamongan (Skripsi

Tidak Dipublikasikan ed.). 
Lamongan: Fakultas-Ekonomi Universitas Lamongan.

Riyanto, B. (2010). Dasar-dasar

Pembelajaran Perusahaan.

Yogyakarta: BPFE.

Umar, H. (2010). Riset Pemasaran dan Perilaku Konsumen. Jakarta: PT. Gramedia Pustaka Utama. 